\title{
ELIMINATION OF GREENHOUSE GAS EMISSION DUE TO IMPROVEMENT OF BIODEGRADABLE WASTE MANAGEMENT SYSTEM
}

\author{
Ruta Bendere 1* $^{*}$ \\ Inara Teibe ${ }^{2}$ \\ Dace Arina ${ }^{3}$ \\ Janis Lapsa ${ }^{4}$ \\ ${ }^{1 ; 3}$ Waste Management Association of Latvia, Latvia \\ ${ }^{2}$ University of Latvia, Latvia \\ ${ }^{4}$ Riga Technical University, Latvia
}

*Corresponding author: bendere@edi.lv

\begin{abstract}
In order to reduce the emissions of greenhouse gasses (GHG) from landfills, European Union (EU) Landfill Directive 1999/31/EC requires a progressive reduction of the municipal biodegradable waste disposal. The main problem of the waste management system in Latvia is a heavy dependence from the waste disposal at landfills. An insufficient separate waste collection system and a promotion of the landfilling as a major treatment option, leaded to the disposal of $84 \%$ of the total collected municipal waste in 2012 with a high share of the biodegradable waste. Therefore, in Latvia, the volume of emissions due to the activities of the waste management branch was $5.23 \%\left(632.6 \mathrm{CO}_{2}\right.$ eq.) of the total GHG emissions produced in the national economy in 2010 (12 $097 \mathrm{Gg} \mathrm{CO}_{2}$ eq., except the land use, land-use change and forestry). The aim of this research is to revise the current situation of the management of biodegradable waste in Latvia, and to propose the future activities for the practical improvements dealing with biodegradable waste. The Waste Management Planning System (WAMPS) software has been used as an environmental impact analysis tool for the modelling waste management scenarios. The WAMPS software calculates emissions, energy and turnover of waste streams for processes within the waste management system, e.g., waste collection and transportation, composting, anaerobic digestion, and final disposal - landfilling or incineration. The obtained results are presented in four environmental impact categories: acidification, global warming, eutrophication and photo-oxidant formation, which are characterised by a certain emission. It covers an integrated waste management system starting with the activities where products become waste and have been put into the waste bin at waste generation source to the last point, where the waste becomes either useful material (recycled material, biogas or compost) or becomes part of emissions in the environment after its final disposal at landfill or incineration plant.
\end{abstract}

\section{KEYWORDS}

Biodegradable waste, Mathematic modelling, Waste management

https://doi.org/10.15626/Eco-Tech.2014.047 


\section{INTRODUCTION}

The aim of this paper is to find improvements of waste management system in Latvia, in order to reduce disposal of biodegradable waste and to eliminate GHG generation at landfills.

As one of the main problems indicated is that of strong dependence of the Latvian solid waste management (SWM) system on the landfills, which, in turn, entails a number of other problems: a large amount of the disposed waste; not fulfilled targets as to decreasing the disposal of biodegradable waste; as yet a high proportion of biodegradable waste in the total disposed municipal waste; and a low proportion of the recycled household waste (BiPRO, 2012). Also, the non-optimal organisation and performance of the SWM system has given rise to unjustifiably large amounts of GHG emissions, and, consequently, to global environmental impact (Eurostat, 2012; UNFCCC, 2012).

The total yearly production of bio-waste in the EU amounts to 118 to $138 \mathrm{Mt}$ of which around $88 \mathrm{Mt}$ originate from municipal waste and between 30 to $50 \mathrm{Mt}$ from industrial sources such as food processing, and on average, $40 \%$ of EU bio-waste is still landfilled in 2010, but up to $100 \%$ in some Members States (BIO Intelligence, 2011; JRC, 2014). The average structure of deposited waste material at the landfills in Latvia has been estimated in a research project, The Assessments of Dissolved Organic Carbon Parameters in the Landfill Waste Material (2011). The estimated results show that a lot of waste material in general has been disposed at landfills. According the provided measurement the content of disposed waste contains - bio-waste from $50.3 \%$ to 51.7\%; plastic 10.3\% - $11.8 \%$; paper / cardboard 5.7\% $8 \%$, glass $10.9 \%$ - $19 \%$, textile, rubber and leather 3\% - $8.6 \%$; and metal $2 \%-4.6 \%$ (Virsma, 2011).

The EC investigations show that the main food waste producers are households $-42 \%$ and food manufacturing industry - 39\%, but the third bigger producer are named food service and catering sector - 14\% (BIO Intelligence, 2011). The main municipal biodegradable waste streams that generate bio-waste related to European Waste Codes (EWC) are listed as follow:

1) Kitchen and canteen waste (food waste) (20 0108 EWC code);

2) Garden and park waste (20 0201 EWC code);

3) Mixed municipal waste (20 0301 EWC code);

4) Waste from public market (20 0302 EWC code) which includes biodegradable materials equivalent to codes 200108 EWC and 200201 EWC.

\section{STATISTIC DATA ON COLLECTION OF THE MAIN MUNICIPAL BIODEGRADABLE WASTE STREAM}

Officially obtained statistic data on collection of the main municipal biodegradable waste streams in Latvia, mentioned before, are shown in Table 1 (LEGMC, 2014) 
Linnaeus Eco-Tech'14

Kalmar, 24-26 November, Sweden

Main municipal bio-waste streams and their treatment in Latvia, 2005 -2013, Table 1

\begin{tabular}{ccccccccc}
\hline \multicolumn{1}{c}{ Food waste (20 01 08 EWC code) } & \multicolumn{3}{c}{ Garden and park waste (20 02 01 EWC } \\
code) & \\
\cline { 2 - 10 } & Produced & Collected & Recycled & Landfilled & Produced & Collected & Recycled & Landfilled \\
\hline 2005 & 28 & - & - & 85 & - & - & - & 12604 \\
\hline 2006 & 91 & 50 & - & 50 & - & 13010 & 4131 & 17695 \\
\hline 2007 & 93 & 94 & - & 94 & 1926 & 14666 & 7562 & 7446 \\
\hline 2008 & 38 & 50 & - & 50 & 935 & 15526 & 7763 & 7544 \\
\hline 2009 & 33 & 11 & - & 11 & 1156 & 5127 & 3169 & 11654 \\
\hline 2010 & 44 & - & - & - & 996 & 5348 & 4139 & 8257 \\
\hline 2011 & 32 & 888 & - & - & 4126 & 20818 & 10508 & 1799 \\
\hline 2012 & 5090 & 36 & 10 & - & 2381 & 35857 & 13180 & 1320 \\
\hline 2013 & 54 & 33 & 11 & - & 27818 & 29874 & 48808 & 1702 \\
\hline
\end{tabular}

Mixed municipal waste (20 0301 EWC Waste from public market (20 0302 EWC code) code)

\begin{tabular}{ccccccccc}
\hline & Produced & Collected & Recycled & Landfilled & Produced & Collected & Recycled & Landfilled \\
\hline 2005 & 539614 & - & 3246 & 539614 & 363 & - & - & 363 \\
\hline 2006 & 138563 & 884691 & 99752 & 586829 & - & 546 & - & 376 \\
\hline 2007 & 160891 & 745787 & 42015 & 710997 & - & 235 & - & 297 \\
\hline 2008 & 152254 & 670448 & 39698 & 627142 & - & 600 & - & 2 \\
\hline 2009 & 148602 & 533865 & 5 & 594217 & - & 647 & - & - \\
\hline 2010 & 138173 & 512987 & 5 & 568517 & - & 654 & - & - \\
\hline 2011 & 162675 & 412157 & 10828 & 509751 & - & 593 & - & - \\
\hline 2012 & 108340 & 495959 & 35388 & 502206 & - & - & - & - \\
\hline 2013 & 100899 & 510109 & 56469 & 503733 & - & - & - & - \\
\hline
\end{tabular}

The represented data show great discrepancy between different waste streams and the treatment methods. Interpretation of statistic data is characterized by a peculiarity that produced waste amount consist only from reports given by facilities and institutions, and do not include produced waste in households listed in the amount of collected waste. The reports of official data base show, that food waste (20 0108 EWC code) management is not stated as obligatory demand in practice in the country, and a legal possibility to interpret waste codes allows to treat food waste as mixed municipal waste. Nevertheless, significant improvements have been observed for green waste (20 0201 EWC code) management - a total recycled amount grows to 48808 tonnes in 2013, as treatment method mainly is used open windrow composting. Majority of mixed municipal waste (20 0301 EWC code) is recycled in MBT at landfills. Starting with the year 2009 when the demands how to handle waste from catering were stated this stream in Latvia municipal waste data bases was disappearing.

\section{BIO-WASTE TREATMENT OPTIONS}

In order to elaborate the National Waste Management (WM) system for the first WM planning stage (2006-2012), the Latvian territory was divided into ten WM planning regions, in each of them one landfill for solid waste disposal being organised in compliance with the 
EU sanitary requirements. Mainly it was chosen as a low-cost option for final solid waste disposal compared to waste incineration due to a low inhabitant density at territory. Landfilling, also, allows for disposal all materials in the solid waste stream, for any WM system and technology processes (Mc Dougall, et al., 2003; Tchobanoglous, et al., 1993).

Presented data in Table 2 show a WM performance of each WM planning region. Overall, 583069 tonnes of municipal waste have been collected in 2013; in this total amount excluded waste amounts from class septic tank sludge (20 0304 EWC code), waste from sewage cleaning (20 0306 EWC code), bulky waste (20 0307 EWC code), and has been made correction in metal (20 0140 EWC code), where was included amount not corresponding to produced household waste.

According to the statistical data, a large discrepancy is observed between collected and disposed waste amount within regions, and it indicates that waste from industry have been treated as municipal waste, also significant diversion of recycled waste material is noted among regions. As it is shown by the table 2, collected mixed municipal waste was $219 \mathrm{~kg}$ per capita; recycled $30 \mathrm{~kg}$ per capita, and landfilled - $185 \mathrm{~kg}$ per capita.

Municipal waste treatment by MWP regions in 2013, Table 2

\begin{tabular}{llllllll}
\hline WMP region & $\begin{array}{l}\text { Number of } \\
\text { inhabitants } \\
\text { (on 2013) }\end{array}$ & $\begin{array}{l}\text { Collected } \\
\text { mixed MW }\end{array}$ & $\begin{array}{l}\mathrm{kg} \\
\text { capita }^{-1}\end{array}$ & Recycled & $\begin{array}{l}\mathrm{kg} \\
\text { capita }^{-1}\end{array}$ & $\begin{array}{l}\text { Landfilled } \\
\text { capita }^{-1}\end{array}$ \\
\hline Austrumlatgale & 94257 & 3419 & 36 & 400 & 4 & 16792 & 178 \\
\hline Dienvidlatgale & 179336 & 47789 & 266 & 470 & 3 & 52830 & 295 \\
\hline Liepāja & 147274 & 38522 & 262 & 558 & 4 & 31743 & 216 \\
\hline Maliena & 70349 & 5737 & 82 & 1529 & 22 & 7715 & 110 \\
\hline Piejūra & 138959 & 62725 & 451 & 4429 & 32 & 28821 & 207 \\
\hline Pierīga & 883228 & 249799 & 283 & 35664 & 40 & 300266 & 340 \\
\hline Ventspils & 75421 & 19393 & 257 & 733 & 10 & 7255 & 96 \\
\hline Vidusdaugava & 114723 & 14588 & 127 & 584 & 5 & 18418 & 161 \\
\hline Zemgale & 161784 & 38313 & 237 & 2405 & 15 & 27735 & 171 \\
\hline Ziemel̦vidzeme & 158494 & 29823 & 188 & 26190 & 165 & 12158 & 77 \\
\hline Total / average & 2023825 & 510106 & 219 & 72962 & 30 & 503733 & 185 \\
\hline
\end{tabular}

Kḷavenieks reported (Kḷavenieks, 2014) that today less than half of disposed mixed waste could be pre-treated before landfilling (see Table 3). There is planned that waste pretreatment capacity in Latvia, after new infrastructure establishment will reach to 701380 tonnes per year in 2016. Landfilling of mixed MSW without pre-treatment or separation out the biological fraction is common practice in Latvia. Nowadays, this option is reasonably considered as bad practice because associated with environmental and safety risks related to landfill gas collection (Arina, et al., 2012) with a methane (GHG) generation potential, also treatment of leachate and worthless land usage. But the problems arise with a material after pre-treatment process at landfills - it further application and use (see figure 1). 
Linnaeus Eco-Tech'14

Kalmar, 24-26 November, Sweden

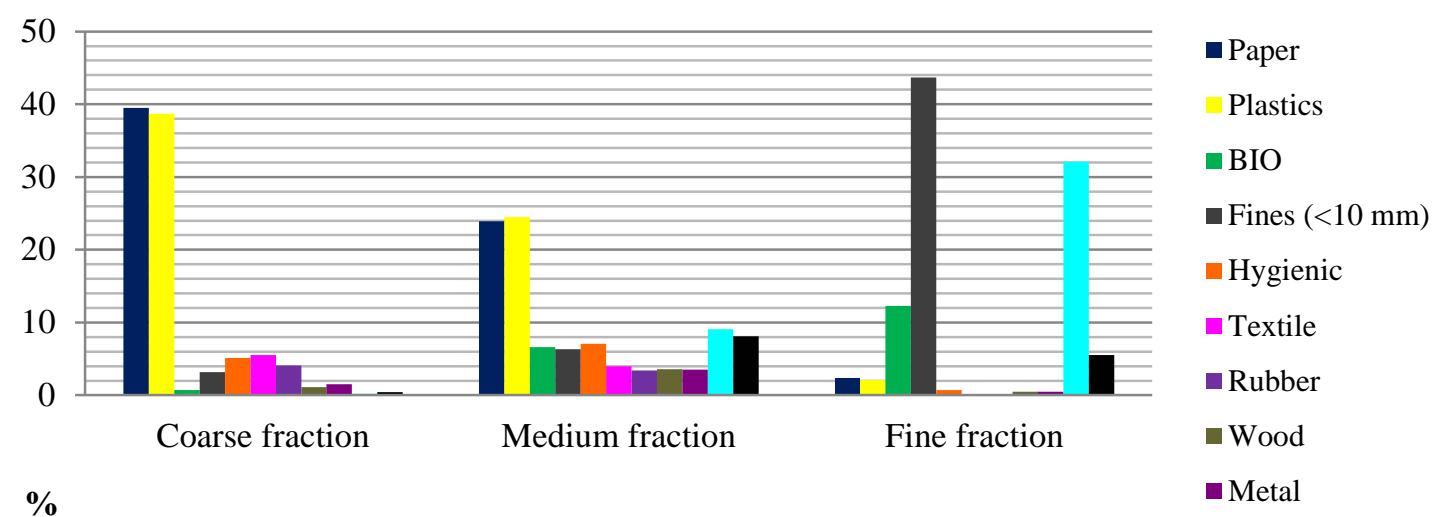

Fig. 1: The average composition of waste fractions after waste pre-treatment by the disc screener (\%, for dry waste)

The results of mechanical sorting of mixed waste show that the coarse fraction, mostly complies with the standard of RDF material of the local cement kiln, content of moisture in all fractions is too high for RDF production, and separated organic fraction is with high pollution level to be used as a compost (Kalnacs, et al., 2013). Therefore, the separation of kitchen and garden waste at source must be a high-priority issue in municipal waste management.

The total compost plants capacity at landfills are $29720 \mathrm{~m}^{2}$, they are designed for composting of small fraction which consists of polluted bio mass. However, a number of municipalities have their own green waste repository, where green waste is stored, managed and used for landscaping, but this amount is not listed in the state report.

Mixed waste pre-treatment capacity in Latvia, Table 3

\begin{tabular}{|c|c|c|c|c|}
\hline WMPR / Operator & Location & $\begin{array}{l}\text { Capacity, } \\
\text { tonnes }\end{array}$ & $\begin{array}{l}\text { Year } \\
\text { established }\end{array}$ & $\begin{array}{l}\text { Compost } \\
\text { plant, } \mathrm{m}^{2}\end{array}$ \\
\hline Ziemel̦vidzeme / ZAAO & Daibe, MBT landfill & 30000 & 2011 & 5632 \\
\hline $\begin{array}{l}\text { Vidusdaugava / Vidusdaugavas } \\
\text { SPAAO }\end{array}$ & Dziḷā vāda, MBT landfill & 80000 & 2012 & 14000 \\
\hline Liepāja / VAAO & Vibsteri , MBT & 40000 & 2012 & \\
\hline Pierīga / Ķilupe & Ķilupe, MSF & 14000 & 2012 & \\
\hline $\begin{array}{lll}\text { Zemgale / Jelgavas } & \text { komunālie } \\
\text { pakalpojumi } & & \end{array}$ & Brakšksi, MBT landfill & 30000 & 2013 & \\
\hline $\begin{array}{l}\text { Ventspils } \\
\text { labiekārtošanas kombināts }\end{array}$ & Pentuli, MBT landfill & 22380 & 2013 & \\
\hline Dienvidlatgale / AADSO & Cinīši, MBT landfill & 60000 & 2015 & 1050 \\
\hline Piejūra / AAS Piejūra & Janvāri, MBT landfill & 40000 & 2015 & 5038 \\
\hline Austrumlatgale / ALAAS & Križevņiki, MBT landfill & 20000 & 2015 & 2000 \\
\hline Piejūra / AAS Piejūra & Jūrmala, MSF & 20000 & 2015 & \\
\hline Alba 5 (AP Kaudzītes) & Kaudzìtes, MBT landfill & 15000 & 2015 & 2000 \\
\hline $\begin{array}{l}\text { Pierīga / } \\
\text { Vides pakalpojumu grupa/Getliņi } \\
\text { EKO }\end{array}$ & Getlini, MBT landfill & 300000 & 2016 & \\
\hline $\begin{array}{l}\text { Liepāja / } \\
\text { EKO Kurzeme/Liepājas RAS }\end{array}$ & Ķīvītes, landfill & 30000 & 2016 & \\
\hline Total mixed waste pre-treatment & $\begin{array}{r}\text { / compost capacity, tonnes: } \\
\text { January, } 2014 \\
\text { January, } 2016 \\
\end{array}$ & $\begin{array}{l}216380 \\
701380 \\
\end{array}$ & & 29720 \\
\hline
\end{tabular}


Dubrovkis et al pointed that 34 biogas plants worked in Latvia in 2012 with a total installed capacity of around $39 \mathrm{MW}$, including 3 biogas plants at landfills - Daibe, Ķīvìtes and Getlini; 1 biogas plant of urban sewage sludge; 2 biogas plants of food industry (biogas is used directly combustion boiler); 1 wood biomass gasification facility, and 27 biogas plants in agriculture (Dubrovskis, et al., 2013).

\section{MATERIALS AND METHODS}

The Waste Management Planning System (WAMPS) software has been used as the environmental impact analysis tool for modelling waste management scenarios. The new version of WAMPS (see Fig. 2) offers the user to create more scenarios for waste management development, as it has been improved with a mechanical pre- treatment process, where new fractions - metal, fine and RDF - are produced. The new waste material technology - incineration in a cement kiln - is also one of the solutions how to use waste as burning material and replace the fossil resources.

The WAMPS software calculates emissions, energy and turnover of waste streams for processes within the waste management system, e.g., waste collection and transportation, composting, anaerobic digestion, and final disposal - landfilling or incineration (IVL, 2013).

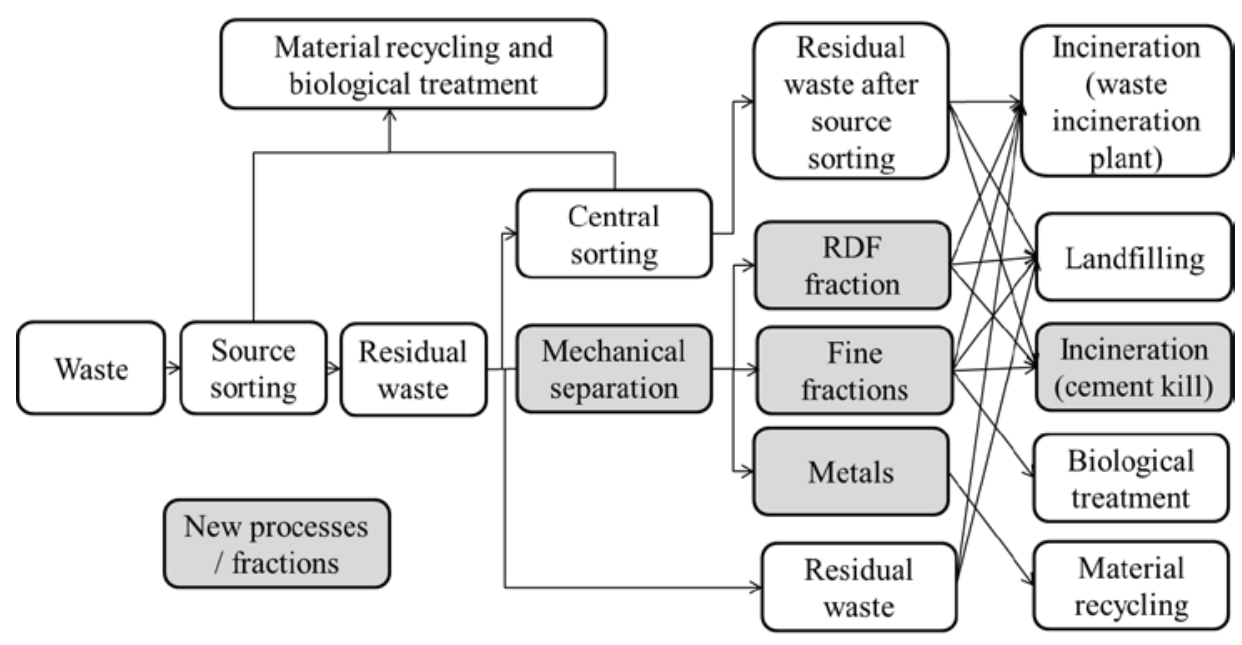

Fig. 2: Overview of WAMPS modelling possibilities

WAMPS software based on the Life Cycle Assessment approach, and the results are presented in four environmental impact categories: acidification, global warming, eutrophication and photo-oxidant formation, which are characterised by a certain emission. This paper focuses only on the global warming category.

WAMPS covers an integrated waste management system starting with the activities where products become waste and have been put into the waste bin at waste generation source to the last point, where the waste becomes either useful material (recycled material, biogas or compost) or becomes part of emissions in the environment after its final disposal at a landfill or incineration plant. The calculation can give also negative net emissions, as an example WM with incineration could give lower emissions than the corresponding energy production in the background system (fossil resource). The net emissions from each of waste management scenarios are calculated after equation (1) (Moora, 2009): 
where,

$$
E_{\text {net }}=E_{\text {waste }}-E_{\text {background }}
$$

$E_{\text {net }}-$ Net emissions (tonnes year ${ }^{-1}$ );

$E_{\text {waste }}$ - Emission from waste process that produce a certain amount of product / energy (tonnes year ${ }^{-1}$ );

$E_{\text {background }}$ - Emission from the same amount of alternative virgin production in the background system (tonnes year ${ }^{-1}$ ).

Also, in the development of the WAMPS software, a number of limitations have been acknowledged.

\subsection{Waste amount and composition}

For the modelling purpose, it is assumed that total collected municipal waste amount correspond to produced amount listed in the public officially available data of municipal waste management form "No. 3-Waste Report", it is 583068 tonnes year ${ }^{-1}$ (see Table 4). The waste from source institutions and small enterprises - consists of amount in a section "Produced waste" of statistic data, and it is 185624 tonnes year ${ }^{-1}$ (LEGMC, 2014). The Eurostat report (Eurostat, 2014) indicats that 64\% of total population live in multi-storey buildings in Latvia. Therefore, rest of total collected municipal waste is shared following: $64 \%$ or 254364 tonnes year ${ }^{-1}$ from multi-storey buildings and $36 \%$ or 143080 tonnes year $^{-1}$ from private houses.

In this case study, it is assumed that waste composition in the country conforms to assessed municipal waste composition of Ogre municipality (39 233 inhabitants). There were sorted and measured 28 tonnes of waste with the waste composition characteristic of the summer season (Bendere, et al., 2014).

Municipal waste composition (tonnes year ${ }^{-1}$ and \% by weight), Table 4

\begin{tabular}{lccc}
\hline & $\begin{array}{c}\text { Institutions and small } \\
\text { enterprises }\end{array}$ & Multi-storey buildings & Private houses \\
\hline Waste amount, tonnes & 185624 & 254364 & 143080 \\
\hline Waste fraction, \% by weight & & & $11 \%$ \\
\hline Paper and cardboard & $32 \%$ & $10 \%$ & $3 \%$ \\
\hline Newspaper, magazines ect. & $7 \%$ & $3 \%$ & $21 \%$ \\
\hline Plastic & $27 \%$ & $28 \%$ & $2 \%$ \\
\hline $\begin{array}{l}\text { Metal packaging (aluminium and } \\
\text { steel) }\end{array}$ & $1 \%$ & $2 \%$ & $8 \%$ \\
\hline Glass & $4 \%$ & $8 \%$ & - \\
\hline Rubber, incl. tyres & - & - & - \\
\hline Clothes, shoes, textiles and leather & - & - & $1 \%$ \\
\hline Wood & - & - & $19 \%$ \\
\hline Biodegradable material (mixed & - & $29 \%$ & $20 \%$ \\
\hline Organic degradable kitchen waste & $10 \%$ & - & - \\
\hline Garden Waste & $14 \%$ & $2 \%$ & $3 \%$ \\
\hline Hazardous waste & $1 \%$ & - & $4 \%$ \\
\hline Electric and electronic wastes & - & $5 \%$ & - \\
\hline WEEE) & $3 \%$ & - & $5 \%$ \\
\hline Inert wastes & - & & \\
\hline Non-hazardous batteries & - & $2 \%$ & \\
\hline
\end{tabular}


Kalmar, 24-26 November, Sweden

\begin{tabular}{lccc}
\hline Others & $1 \%$ & - & $3 \%$ \\
\hline Total & $100 \%$ & $100 \%$ & $100 \%$ \\
\hline
\end{tabular}

1) sorting at source (see Table 5) and mechanical sorting.

The provided inhabitants survey in Marupe municipality (Riga suburb with 10000 inhabitants, of whom 5000 live in private houses) in 2014 shows that two thirds of 171 respondents confirm - they already organizing green waste backyard composting. This aspect is taken in account in order to fulfil Landfill Directives target and requirements on biodegradable waste. It is assumed that all private houses reduce green waste amount at source gradually: $50 \%$ of weight in Scenarios 1 and 100\% - in Scenarios 2 and 3 by home composting.

After estimated statistic data and waste composition, the institutions can fulfil green waste treatment targets and start to separate $100 \%$ of produced green waste. The treatment can be done using open windrow composting. The third largest producer of food waste - food service and catering sector is taken into account in Scenario 2, but households living in multistorey buildings are added in Scenario 3.

Currently, the Waste Framework Directive objectives are very ambitious for Latvia, so it is chosen less ambitious goal - 25\% source sorting of waste materials: paper / cardboard, glass, plastic and metal in the Scenarios 1 to 3 (see Table 5).

Waste sorting at source of studied waste management scenarios, Table 5

\begin{tabular}{lcccccccc}
\hline Scenario & $\begin{array}{l}\text { Paper } \\
\text { cardboa } \\
\end{array}$ & & Glass & Plastic & Metal & \multicolumn{2}{c}{ Food waste } & \multicolumn{2}{c}{ Green waste } \\
\cline { 6 - 10 } & & & & Institutions & $\begin{array}{c}\text { Multi-storey } \\
\text { buildings }\end{array}$ & $\begin{array}{c}\text { Institutions } \\
\text { Private } \\
\text { houses }\end{array}$ \\
\hline Base & $4 \%$ & $1 \%$ & $1 \%$ & $1 \%$ & & $<1 \%$ & $100 \%$ & - \\
\hline Scenario 1 & $25 \%$ & $25 \%$ & $25 \%$ & $25 \%$ & - & - & $100 \%$ & $50 \%$ \\
\hline Scenario 2 & $25 \%$ & $25 \%$ & $25 \%$ & $25 \%$ & $100 \%$ & $100 \%$ & $100 \%$ \\
\hline Scenario 3 & $25 \%$ & $25 \%$ & $25 \%$ & $25 \%$ & $100 \%$ & $100 \%$ & $100 \%$ \\
\hline
\end{tabular}

After source sorting of waste material (paper, plastics, glass, metallic packages and bio-waste) rest of waste - mixed waste is transported to landfill equipped with mechanical sorting line for pre-treatment process. After results of investigation (Kalnacs, et al., 2013), the four fractions are separated from the total mixed household waste mass, i.e.:

$\sim 35 \%$ - fine fraction mainly composed of organic waste;

$\sim 40 \%$ - medium fraction of diversified waste;

$\sim 22 \%$ - coarse fraction (RDF) containing waste of high calorific value (plastics, paper, textile, rubber);

$\sim 3 \%$ - iron-containing.

This percentage was used in mechanical sorting calculations of calculated waste management scenarios.

\subsection{Waste management scenarios and used technologies}

A base scenario and three alternative scenarios is developed for Latvian waste management system. The studied scenarios are hypothetical and characterise possible food waste and green waste management development trends in Latvia, in order to reduce GHG emissions. Base scenario conforms to existing situation in the country. 
Linnaeus Eco-Tech'14

Kalmar, 24-26 November, Sweden

Main characteristics of studied waste management scenarios, Table 6

\begin{tabular}{|c|c|c|c|c|c|c|c|c|c|}
\hline \multirow[b]{2}{*}{ 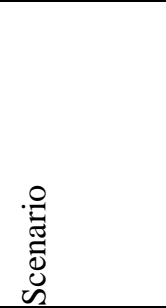 } & \multirow{2}{*}{ 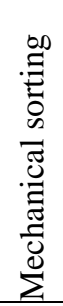 } & \multicolumn{3}{|c|}{$\begin{array}{l}\text { Biodegradable organic waste } \\
\text { (after source sorting) }\end{array}$} & \multirow{2}{*}{$\begin{array}{l}\text { Fine fraction } \\
\text { (after mechanical } \\
\text { sorting) } \\
\text { Composted and } \\
\text { used as covering } \\
\text { material for } \\
\text { disposal site }\end{array}$} & \multicolumn{3}{|c|}{$\begin{array}{l}\text { RDF fraction } \\
\text { (after mechanical sorting }\end{array}$} & \multirow[t]{2}{*}{ Landfill } \\
\hline & & 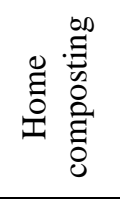 & 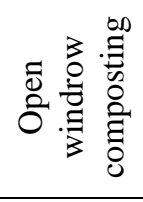 & 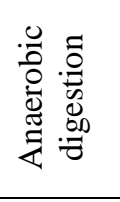 & & 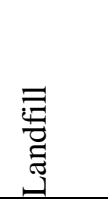 & 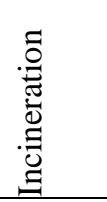 & 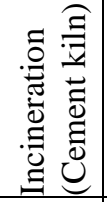 & \\
\hline Base & + & & $100 \%$ & & $100 \%$ & $100 \%$ & & & $100 \%$ \\
\hline Scenario 1 & + & $35 \%$ & $65 \%$ & & $100 \%$ & $80 \%$ & $10 \%$ & $10 \%$ & $100 \%$ \\
\hline Scenario 2 & + & $\begin{array}{l}52 \% \text { of } \\
75 \% *\end{array}$ & $\begin{array}{l}48 \% \text { of } \\
75 \% *\end{array}$ & $25 \%$ & $100 \%$ & $80 \%$ & $10 \%$ & $10 \%$ & $100 \%$ \\
\hline Scenario 3 & + & $\begin{array}{l}53 \% \text { of } \\
30 \% *\end{array}$ & $\begin{array}{l}47 \% \text { of } \\
30 \% *\end{array}$ & $70 \%$ & $100 \%$ & $80 \%$ & 10 & 11 & 100 \\
\hline
\end{tabular}

*were $100 \%$ - total composted fraction

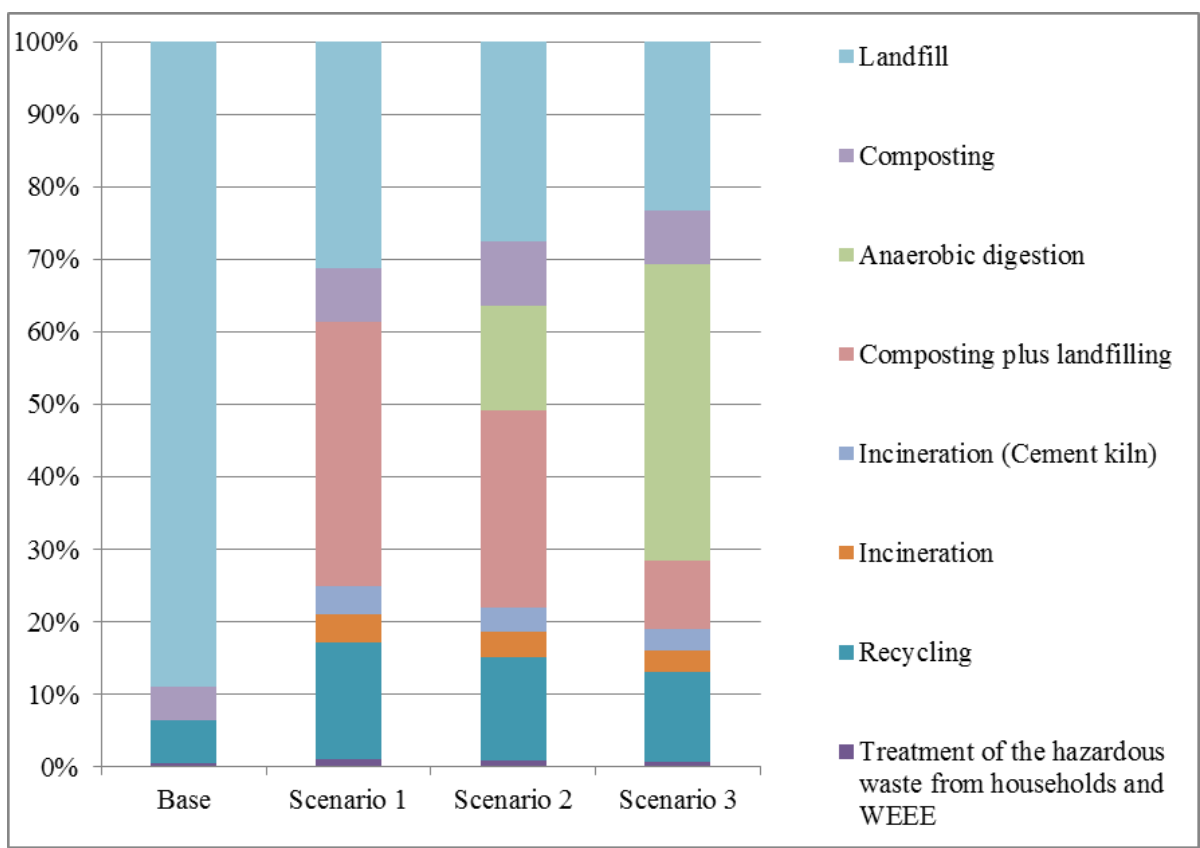

Fig. 3: Projection of treatment of studied waste management scenarios (\% by weigh)

The assumptions taken in the mathematic design of the models are (see Table 6 above):

a) it is assumed that biodegradable waste composting produce the compost that is $60 \%$ from the total mass, and it is used as fertiliser for landscaping, agricultural or local consumption at home;

b) in all scenarios it is assumed that energy produced from landfill gas and waste incineration replaces fossil fuel in a background system - natural gas;

c) in all scenarios it is assumed that landfill gas is recovered and combusted with $35 \%$ efficiency (Arina, et al., 2012; Sonesson, et al., 1997) - 50\% of district heating and $40 \%$ of electricity;

d) the incineration complies with EU requirements, and it is assumed that energy recovery from incineration process is $20 \%$ of electricity and $80 \%$ district heating. 


\section{RESULTS}

The LCA modelling results of studied scenarios show that biodegradable waste avoiding from disposal in landfills leads to significant reduction of GHG. The global warming of analysed scenarios is shown in Figure 4 and Table 7.

\section{Global warming}
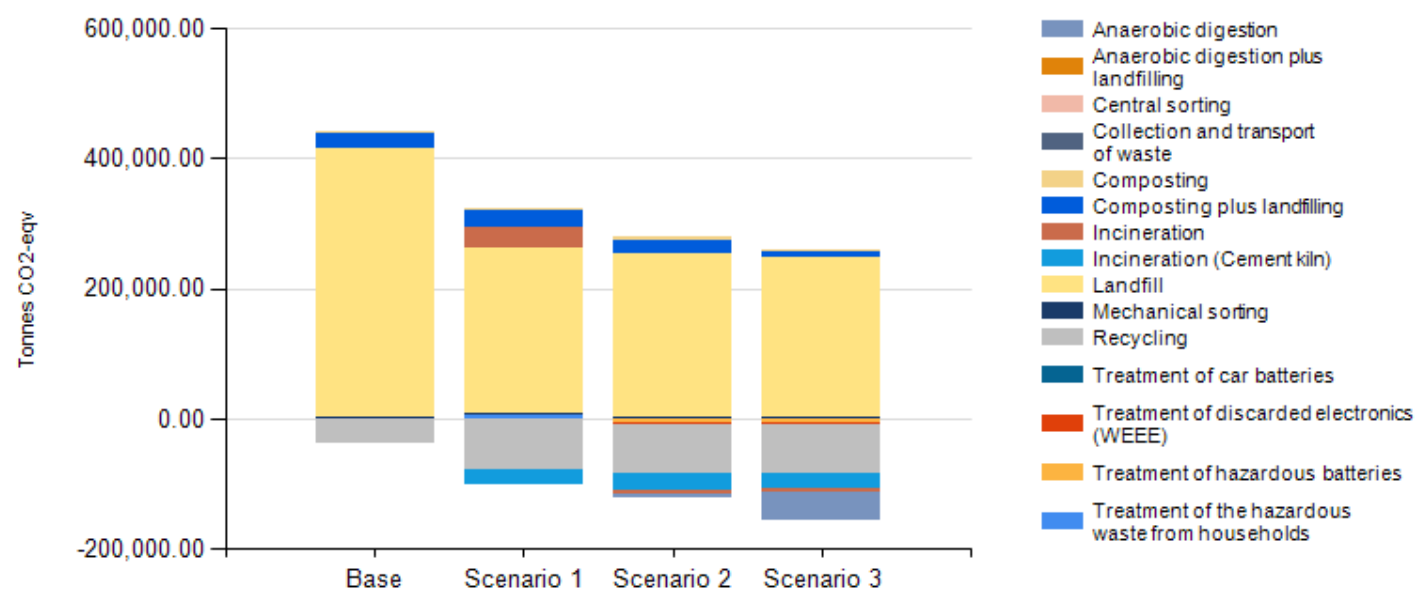

Fig.4: Overview of global warming from studied waste management scenarios (tonnes $\mathrm{CO}_{2}$ eqv)

The diagrams show net emissions from each waste management technology minus saved emissions in the background system. Negative results show avoided impacts and saving of fossil fuel.

Total designed GHG emission shows reduction from 404700 tonnes $\mathrm{CO}_{2}$ eqv (Base scenario); 222127 tonnes $\mathrm{CO}_{2}$ eqv (Scenario 1); 158526 tonnes $\mathrm{CO}_{2}$ eqv (Scenario 2) to 92333 tonnes $\mathrm{CO}_{2}$ eqv (Scenario 3).

Global warming emissions by each waste treatment technology (tonnes $\mathrm{CO}_{2}$ eqv.), Table 7

\begin{tabular}{|l|c|c|c|c|c|c|}
\hline & $\begin{array}{l}\text { Anaerobic } \\
\text { digestion }\end{array}$ & Composting & $\begin{array}{l}\text { Composting } \\
\text { plus landfilling }\end{array}$ & Incineration & $\begin{array}{l}\text { Incinerati } \\
\text { on } \\
\text { (Cement } \\
\text { kiln) }\end{array}$ & Landfill \\
\hline Base & - & 2981 & 23159 & - & - & 415037 \\
\hline Scenario 1 & - & 4526 & 24569 & -32346 & -24497 & 255230 \\
\hline Scenario 2 & -6836 & 5891 & 20746 & -7152 & -24104 & 252958 \\
\hline Scenario 3 & -43162 & 5422 & 8301 & -6284 & -22853 & 246070 \\
\hline & $\begin{array}{l}\text { Mechanical } \\
\text { sorting }\end{array}$ & Recycling & $\begin{array}{l}\text { Treatment } \\
\text { discarded } \\
\text { electronics } \\
\text { (WEEE) }\end{array}$ & $\begin{array}{l}\text { Treatment of } \\
\text { hazardous } \\
\text { batteries }\end{array}$ & $\begin{array}{l}\text { Treatment } \\
\text { hazardous } \\
\text { households }\end{array}$ & of \\
waste \\
from \\
\hline Base & 1619 & -36533 & -1548 & -109 & & 95 \\
\hline Scenario 1 & 1485 & -76897 & -1998 & -4842 & & -1662 \\
\hline Scenario 2 & 1372 & -76897 & -1998 & -4842 & & -1662 \\
\hline Scenario 3 & 1016 & -76897 & -1998 & -4842 & & -1662 \\
\hline
\end{tabular}




\section{CONCLUSIONS}

Landfill (Base Scenario), as final disposal waste treatment method, is a major source of GHG emissions, mainly $\mathrm{CH}_{4}$, despite of the fact assumed that all landfills gas is collected and recovered.

A significant net impact give material recycling and incineration, especially an incineration in cement kiln, when materials are recycled and produced heat and electricity that allows to save virgin materials and fossil fuels. It also reduce disposed amount in landfills.

The sorting of food waste at source and reduction of its content in the fine fraction for composting and landfilling - increase options to use food waste as valuable material and reduce significantly disposed waste amount in landfills. Also the food waste separated at source presents significant input material for energy recovery and energy production from biogas which displaces energy largely based on fossil fuels (coal, oil, gas).

Composting may results in $\mathrm{CO}_{2}$ emission from organic matter decomposition process, also after the compost is added to the soil and from mechanical turning of the compost pile. If composting process is managed properly, then $\mathrm{CH}_{4}$ emission does not appear from anaerobic decomposition.

Current statistic data show insufficiency of reliable data of produced food waste amount and its content which reduce the effectiveness of waste treatment planning. Therefore pilot research results are extremely necessary.

In a system perspective, it is essential requirement to prepare food waste for anaerobic digestion in planned capacity and constant quality, therefore food waste thermal stabilisation is desirable.

In order to manage food waste anaerobic digestion feasible (composting only food waste without any other organic material will be extremely difficult), establishment of new or integration in existing alternative systems for energy and digest consumption is necessary. The rationale is to combine production with agriculture, transport or other utilities.

The green waste composting is rational option, if the produced compost is valuable and is needed as soil improver. Therefore government has to create legislative and economical instruments how to adequately stimulated compost market and use produced material for landscaping, road construction projects or others.

Home composting in private houses, in case of Latvia, is very feasible and it allows reduce significantly treated municipal waste amount. Therefore local municipal support and campaigns of home composting awareness arising is extremely necessary. 


\section{REFERENCES}

Arina, D., Bendere, R. \& Teibe, I., 2012. Pre-treatment Processes of Waste Reducing the Disposed Amount of Organic Waste and Greenhouse Gas Emission. Florence, The ISWA World Solid Waste Congress 2012, p. 517 pdf.

Barton, R., Dalley, D. \& Patel, V., 1996. Life Cycle Assessment for Waste Management. Waste Management, 16(Nos 1-3), pp. 35-50.

Bendere, R., Teibe, I. \& Arina, D., 2014. Finding sound bio-waste treatment solutions in the Baltic states. Athens, National Technical University of Athens.

BIO Intelligence, S., 2011. Preparatory Study on Food Waste Across EU 27, bez viet.: European Communities.

BiPRO, 2012. Screening of Waste Management Performance of EU Member States, Brisele: European Commission.

Boer, E., Boer, J. \& Jager, J., 2005. Waste management planning and optimisation. Handbook for municipal prognosis and sustainability assessment of aste managemnt systems. 1st red. Stuttgart: Ibidem- Verlag.

Dubrovskis, V., Niklass, M., Emsis, I. \& Kārklin̦š, A., 2013. Biogāzes ražošana un efektīva izmantošana, Rīga: Latvijas Biogāzes asociācija.

Eurostat, 2012. Greenhouse gas emissions by sector, Luxemburg: Eurostat.

IVL, 2013. Joint Baltic Sea Region Strategy for Municipal Waste Management, s.l.: s.n.

JRC, 2014. End-of-waste criteria for biodegradable waste subjected to biological treatment (compost \& digestate): Technical proposals, Luxembourg: bez nos.

Kalnacs, J., Arina, D. \& Murashov, V., 2013. Content and Properties of Mechanically Sorted Municipal Wastes and Their Suitability for Production of Alternative Fuel. Renewable Energy \& Power Quality Journal, pp. pp 1-4.

Kḷavenieks, K., 2014. Eiropas Savienības fondu 2014. - 2020. gada finanšu plānošanas perioda potenciāli atbalstāmo vides aizsardzības aktivitāšu ekonomisko ieguvumu novêrtējums, Riga: Geo Consultants, SIA.

LEGMC, 2014. Valsts statistisko pārskats "3-Atkritumi" (State Statistical Review "3-Waste"), Riga: bez nos.

Mc Dougall, F., White, P., Franke, M. \& Hindle, P., 2003. Integrated Solid Waste Management: a Life Cycle Inventory. In: Integrated Solid Waste Management: a Life Cycle Inventory. Oxford: Blackwell Science, p. 513.

Moora, H., 2009. Life Cycle Assesment as a Decision Support Tool for System Optimisation the Case of Waste Management in Estonia. Tallinn: Tallinn Iniversity of Technology. 
Sonesson, U., Jonsson, H., Mingarini, K. \& Dalemo, M., 1997. ORWARE - A simulation model for organic waste handling systems. Part 2: Case study and simulation results. Resources, Conservation \& Recycling, Sep, 21(1), pp. 39-54.

Tchobanoglous, G., Theisen, H. \& S, V., 1993. Integrated Solid Waste Management. Engineering Principles and Management Issues. Singapore: McGraw-Hill Book Co.

UNFCCC, 2012. National Inventory Submissions, bez viet.: United Nations Framework Contention on Climate Change.

Verghese, K. L., 2009. Life cycle assessment and waste management. \%1Life Cycle Assessment: Principles, Practice, and Prospects. bez viet.:CSIRO, pp. 51-68.

Virsma, 2011. Degradējamā organiskā oglekļa daļas noteikšana apglabātos atkritumos, Rīga: Ziņojums.

Housing statistics, 2014.

Http://epp.eurostat.ec.europa.eu/statistics_explained/index.php/housing_statistics 